\title{
Building Assets Toolkit: Developing Positive Benchmarks for Adolescent Girls-Asset Cards
}

Judith Bruce

Population Council

Sarah Engebretsen

Population Council

Kimberly Glazer

Follow this and additional works at: https://knowledgecommons.popcouncil.org/departments_sbsr-pgy

Part of the Family, Life Course, and Society Commons, Health Communication Commons, International Public Health Commons, and the Women's Health Commons How does access to this work benefit you? Let us know!

\section{Recommended Citation}

Bruce, Judith, Sarah Engebretsen, and Kimberly Glazer. 2015. "Building Assets Toolkit: Developing Positive Benchmarks for Adolescent Girls-Asset Cards." New York: Population Council. 


\section{Building Assets Toolkit \\ DEVELOPING POSITIVE BENCHMARKS FOR ADOLESCENT GIRLS}

The Building Assets Toolkit is an approach for developing programs for specific segments of girls that will prepare them to better face the challenges of growing up. It will help you understand the needs of the girls in your community; engage stakeholders at different levels and with different viewpoints; and build concrete and meaningful programming for adolescent girls.

Before you begin this exercise, print out the Instruction Guide and the

Resource Manual. The Guide provides step-by-step instructions on how to use the materials provided here, and the Manual contains valuable information about building meaningful program content as well as detailed notes on each asset.

\section{THIS DOCUMENT CONTAINS:}

1 The set of eight age cards (ranging from ages 6 to 20). Print them out and place them according to the instructions.

(2) 110 asset cards. Print them out and cut each sheet in half. The (2) blanks are provided for you to create customized assets.

(3) The Program Planning Worksheet. A sample is also provided. 

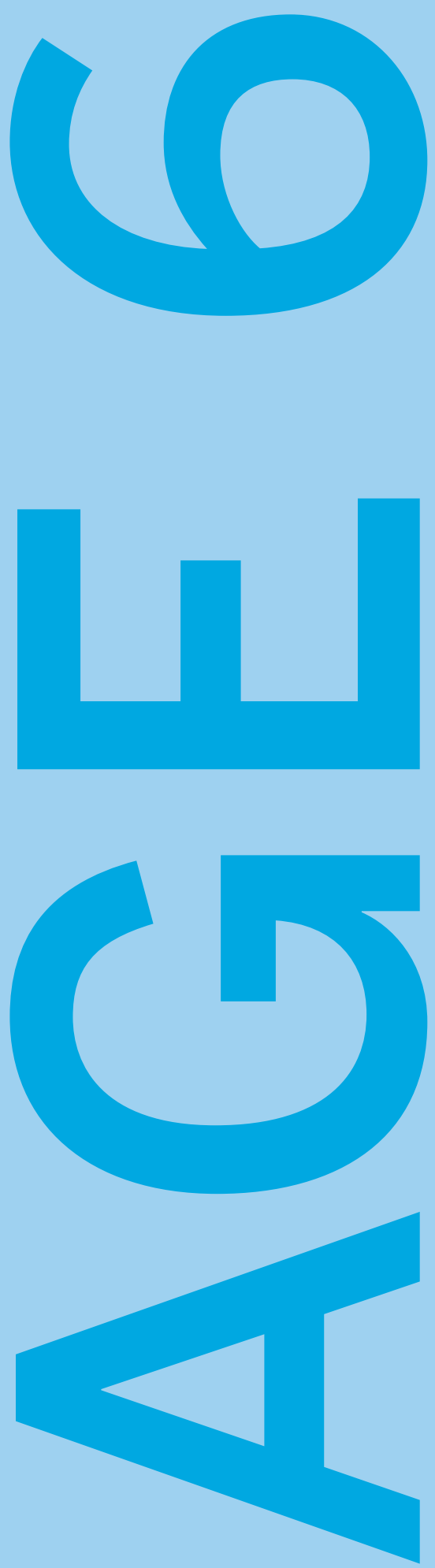

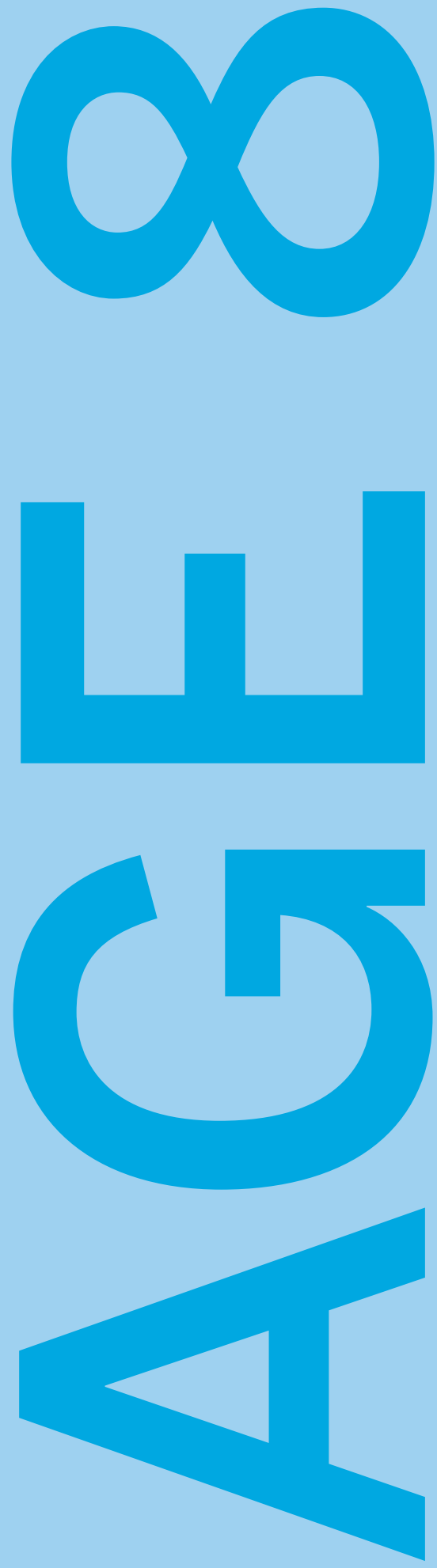

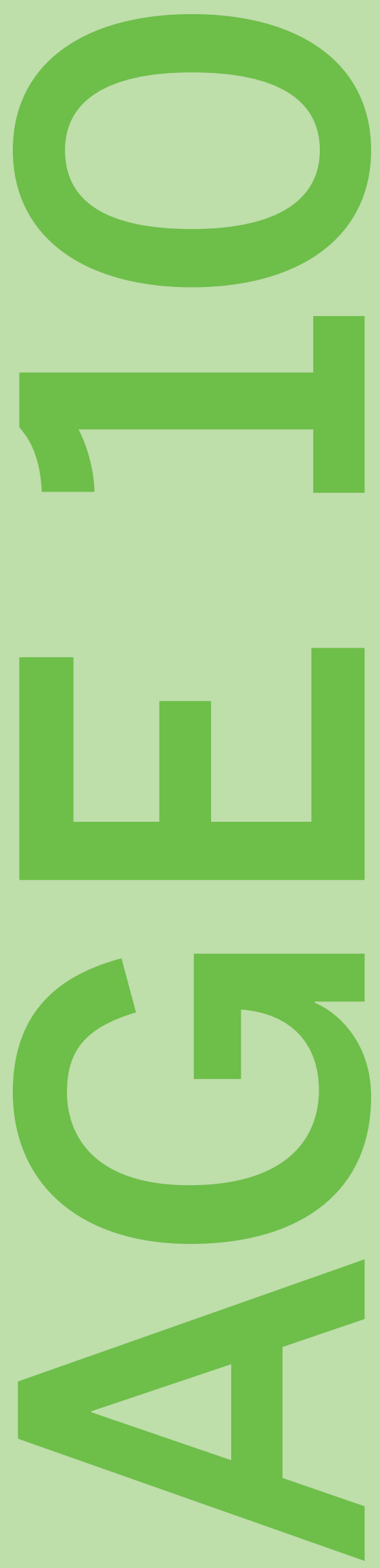

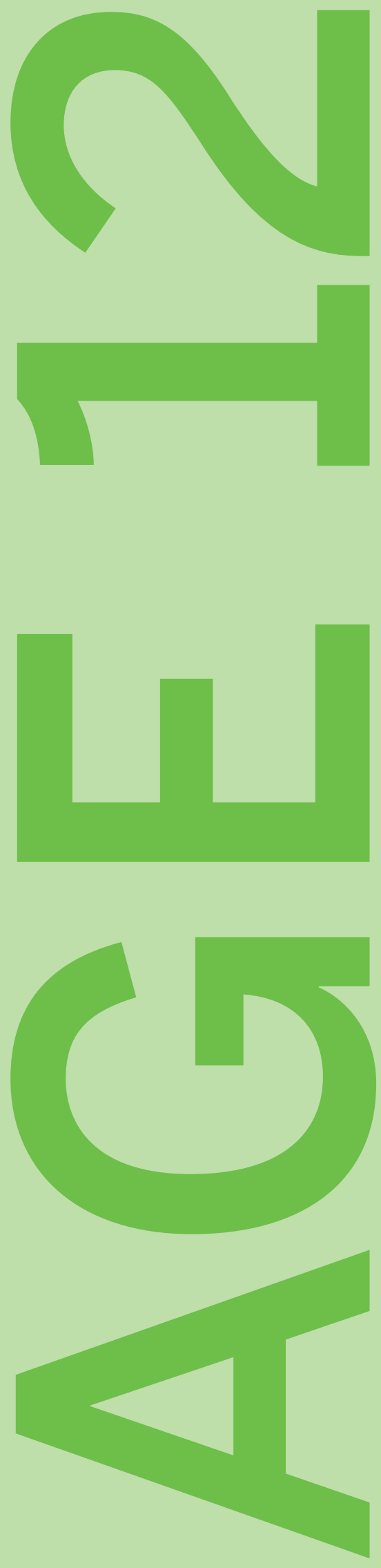

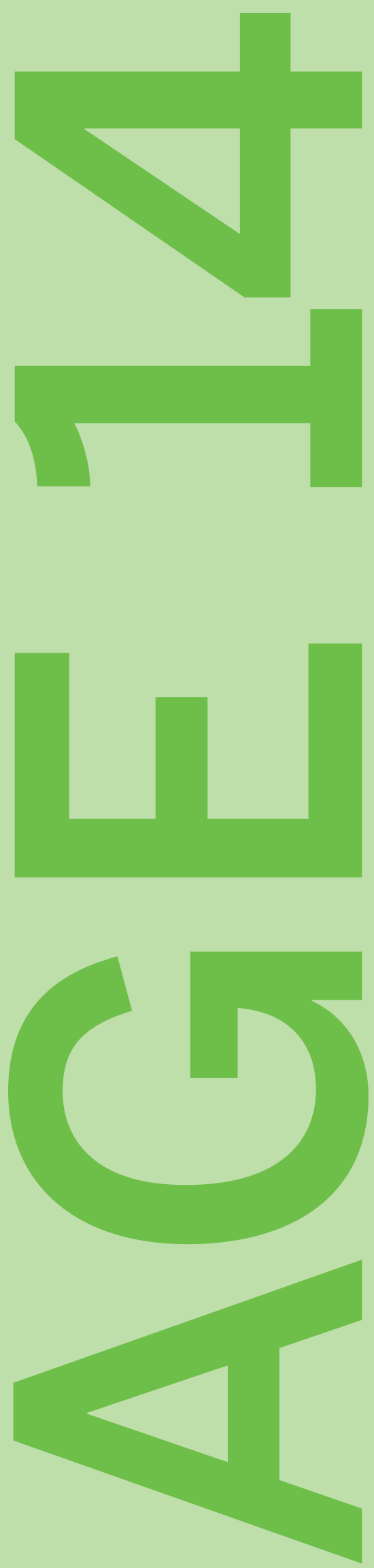

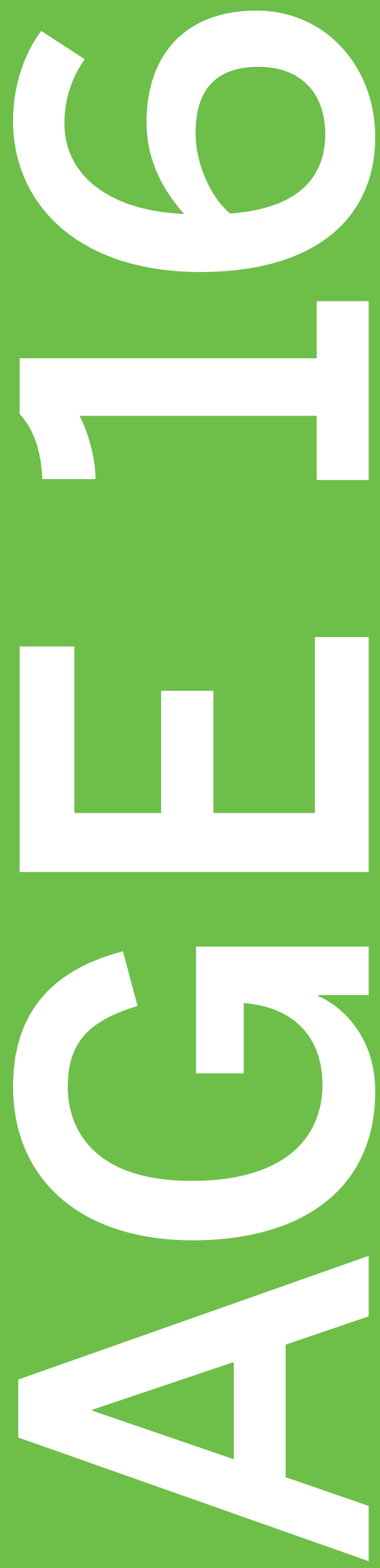


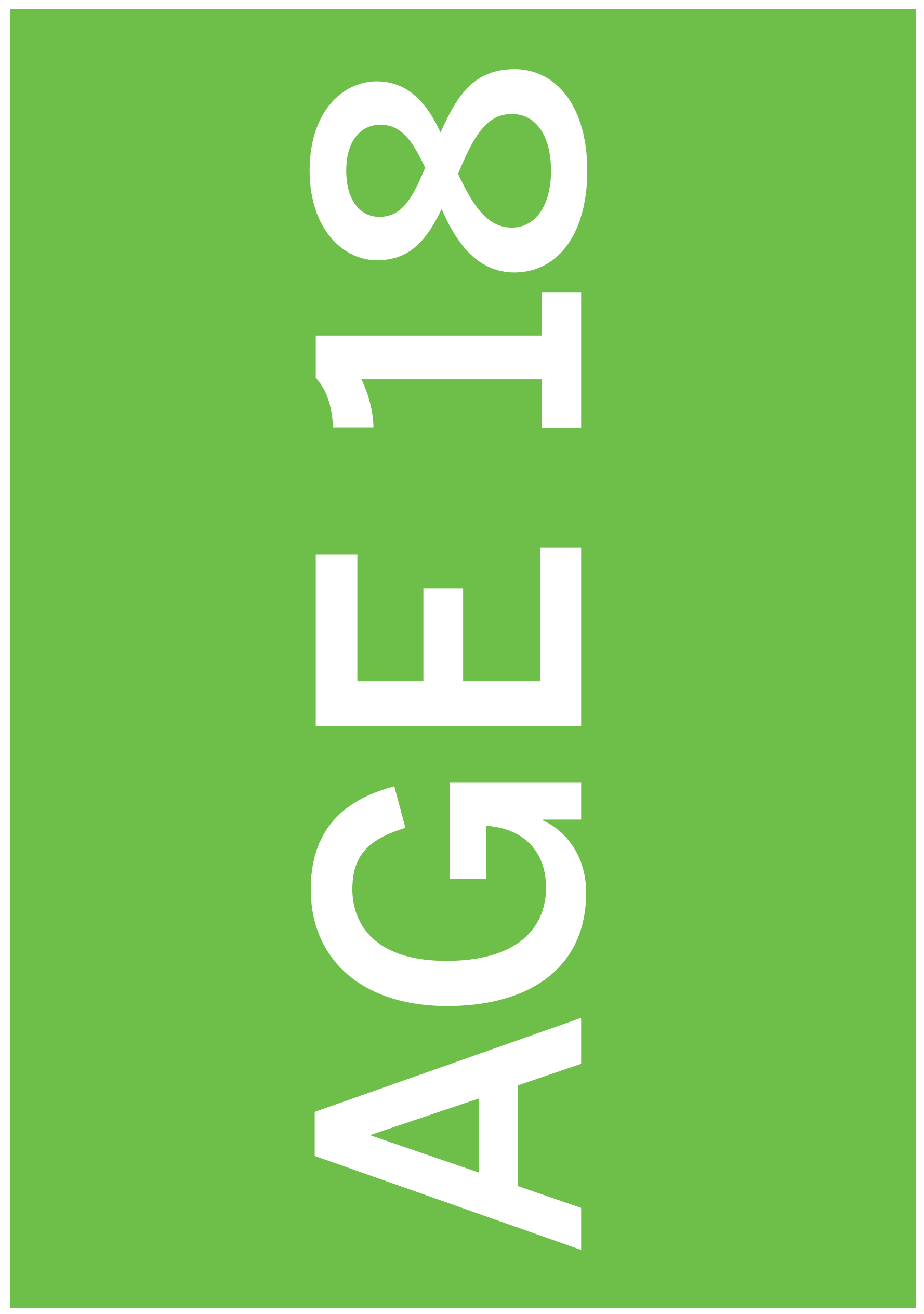




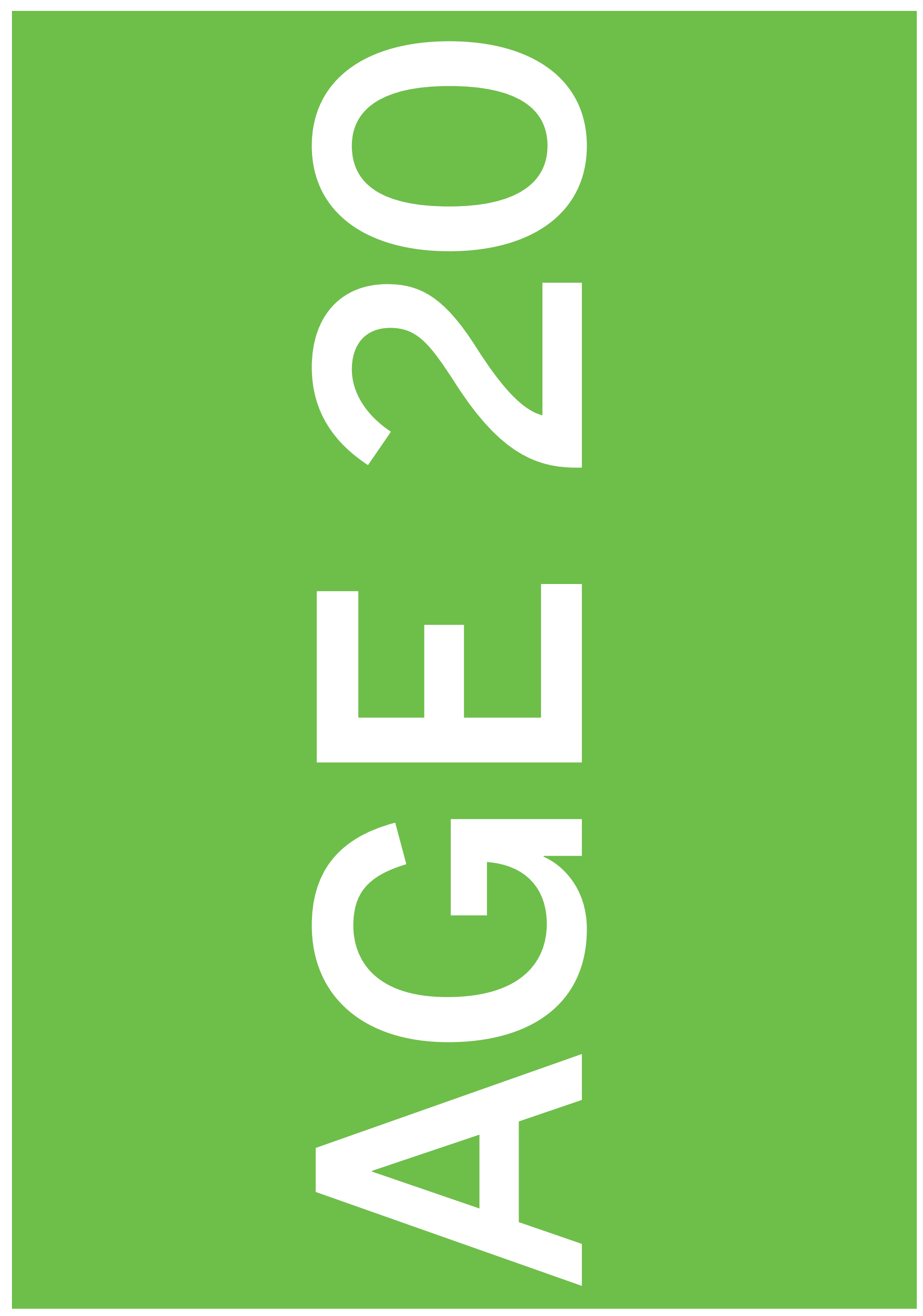




\section{Know the location}

of community rescue places

\section{Know the location of}

the nearest emergency

health services and at

least two conditions

that require

emergency attention 


\section{Have savings that can be accessed in case of a personal emergency or a household shortfall}

\begin{tabular}{|c|c|}
\hline $\begin{array}{l}\text { Building } \\
\text { Assets } \\
\text { Toolkit }\end{array}$ & $\begin{array}{l}\text { DEVELOPING } \\
\text { POSITIVE } \\
\text { BENCHMARKS } \\
\text { FORADOLSCENT } \\
\text { GIRLS }\end{array}$ \\
\hline
\end{tabular}

\section{Have a place to meet friends safely and privately at least once a week}




\section{Have a plan to visit the nearest bank or}

other financial service

facility, with friends

\section{or a parent}

\begin{tabular}{l|l}
\hline Building & DEVELOPING \\
POSTIIE \\
Assets & BENCHMARKS \\
Toolkit & FRRADOLESCENT \\
GIRLS
\end{tabular}

\section{Know where the} nearest police station is and the kind of help the police can provide 


\section{Know the signs of diarrhea in a child and how to treat it}

\section{Know where to get an HIV test}




\section{Have the skills to}

create a budget and know how to track income and spending

\section{Know to ask for} a female authority if she is uncomfortable with a male 


\section{Have at least three female nonfamily friends}

\section{Have the personal documentation}

needed to access financial services 


\section{Have the personal documentation}

needed to access health services

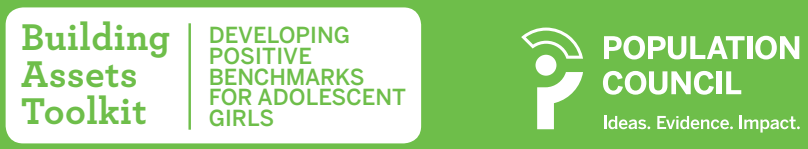

Have a slightly older female mentor she

can turn to for advice when faced with challenges 


\section{Know how to play traditional games}

\begin{tabular}{l|l} 
Building & DEVELOPING \\
POSSTIVE \\
Assets & BENCHMARKS \\
Toolkit & FORADLLESCENT \\
\hline
\end{tabular}

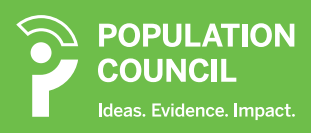

\section{Have a productive skill that earns money}




\section{Be able to use \\ decisionmaking \\ skills to differentiate \\ safe and unsafe \\ earning options}

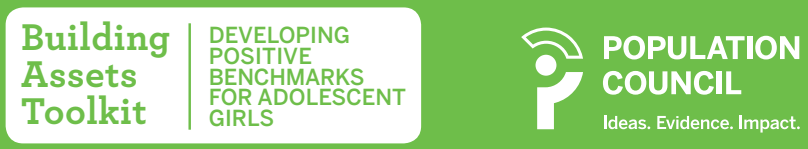

Know the specifics

of menstruation and

how to safely and

cleanly manage it 


\section{Know when to wash}

hands and how to do

it properly in daily

life and in the context

of infectious disease

outbreaks

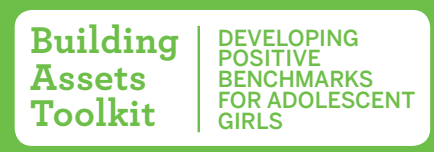

POPULATION
COUNCIL
Ideas. Evidence. Impact.

Be aware of daily and seasonal

demands on her

time and know how

to budget her time 


\section{Know about female}

genital mutilation (how and when it is done, how to help someone threatened by it, and that it is illegal)

Use negotiation, specific knowledge of risk scenarios, and problemsolving skills to avoid harmful traditions (like FGM) common in her community 


\section{Have someone to \\ borrow money from \\ in an emergency}

\begin{tabular}{l|l} 
Building & DEVELOPING \\
POSSTIIE \\
Pssets & BENCHMARKS \\
Toolkit & FIRADLLESCENT \\
\hline
\end{tabular}

POPULATION
COUNCIL
Ideas. Evidence. Impact.

Know the teachers' code of behavior

(including not asking

students for special

favors or inviting

them to their homes) 


\section{Identify someone to}

go to for help in case

of abuse at school

and know where to

report abuse

\begin{tabular}{l|l} 
Building & DEVELOPING \\
AOSTIIVE \\
Assets & BENCHMARKS \\
Toolkit & FORADOLESCENT \\
GIRLS
\end{tabular}

POPULATION
COUNCIL
Ideas. Evidence. Impact.

25

Know where to go to get basic medicines and have the

money necessary to purchase them 


\section{Have a safe place to spend the night away from home, if needed}

\begin{tabular}{l|l} 
Building & DEVELOPING \\
POSSTIIE \\
Pssets & BENCHMARKS \\
Toolkit & FIRADLLESCENT \\
\hline
\end{tabular}

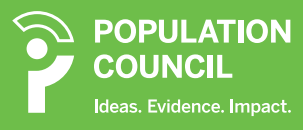

Know signs of danger during pregnancy and labor, and where to go for help 


\section{Know the name of the district in which she lives}

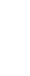

\section{Have the ability to}

tell her parents that what they want her to do is illegal 


\section{Know the seasonal risks and stresses}

\section{on her family's}

livelihood/income

\begin{tabular}{l|l} 
Building & DEVELOPING \\
PSs POITEE \\
Toots & BENCHMARKS \\
FORADLESCENT \\
GIRLS
\end{tabular}

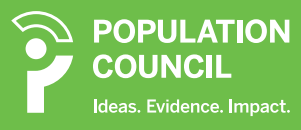

\section{Have short-term}

financial goals and a

plan to meet them 


\section{Have long-term}

financial goals and a

\section{plan to meet them}

\section{Have considered} carefully what skills she would need to engage in earning activities that she

\section{enjoys}




\section{Know the minimum}

number of school years to which she's entitled

\section{Have the negotiation} and problem-solving skills to assert her preference for staying in school 


\section{Understand the biological basics of sexuality and reproduction}

\section{Be able to describe}

something unique or special about herself and identi-

fy a skill that she can teach others 


\section{Know how to}

distinguish between a required expense and one that can be

\section{postponed}

\section{Know the \\ advantages and \\ disadvantages of \\ two to three savings \\ options}




\section{Know how HIV is}

transmitted, how to

prevent it, where to be

tested, and that there

are treatment options

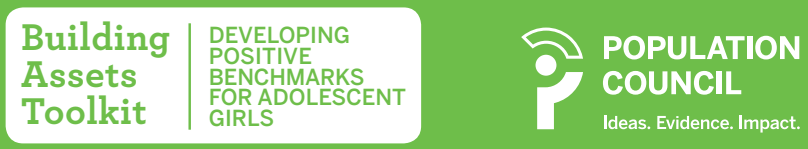

\section{Know the legal age of work and basic approved conditions}


Know the signs and dangers of drug and alcohol dependence, and where to seek help for herself or someone else

\begin{tabular}{l|l} 
Building & DEVELOPING \\
POSIIIVE \\
Assets & BENCHMARKS \\
Toolkit & FORADOLESENT \\
GIRLS
\end{tabular}

$$
\begin{aligned}
& \text { POPULATION } \\
& \text { COUNCIL } \\
& \text { Ideas. Evidence. Impact. }
\end{aligned}
$$

\section{Have a place with} sufficient light to read for three hours

$$
\text { per week }
$$




\title{
Know the legal
}

voting age, where to

register, and where

$$
\text { to vote }
$$

\begin{tabular}{l|l}
\hline Building & DEVELOPING \\
POSTIIE \\
Assets & BENCHMARKS \\
Toolkit & FORADOLESCENT \\
GIRLS
\end{tabular}

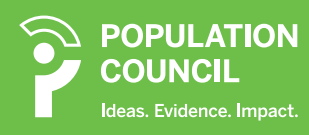

\section{Know what the}

community council

does, when it meets,

\author{
and some of the \\ official leaders
}




\section{Know whom to ask/}

where to ask for help if she or someone she knows is a victim of violence

\begin{tabular}{|c|c|}
\hline $\begin{array}{l}\text { Building } \\
\text { Assets } \\
\text { Toolkit }\end{array}$ & $\begin{array}{l}\text { DEVELOPING } \\
\text { POSIIIVE } \\
\text { BENCHMARKS } \\
\text { FOR ADOLESCENT } \\
\text { GIRLS }\end{array}$ \\
\hline
\end{tabular}

\section{Know that violence}

isn't just stranger

violence-it often

occurs in families 


\section{Know basic self- \\ defense and ways to attract help}

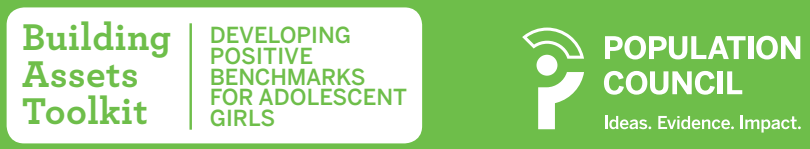

\section{Know what abuse is}

and the difference between a "good touch" and a "bad touch" 


\section{Know when she is}

hungry and have the courage to tell someone safe that she feels hungry

Know how to obtain/ raise a few key foods she needs to eat 


\section{Know that adolescent} girls need more food than younger girls (specifically more

$$
\text { protein) }
$$

\begin{tabular}{l|l}
\hline Building & DEVELOPING \\
POSTIVE \\
Assets & BENCHEARKS \\
Toolkit & FORADOLESENT \\
GIRLS
\end{tabular}

Be able to read a sentence in her native language 


\section{Know how to}

\section{describe/express a} problem to someone in authority, such as

$$
\text { a local official }
$$

\begin{tabular}{l|l} 
Building & DEVELOPING \\
Assets & PENTIIE \\
BENCHMARKS \\
Toolkit & FORADLLESCENT \\
GIRLS
\end{tabular}

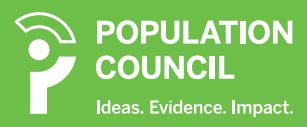

Have a government ID (such as one that would be necessary for voting) 


\section{Know about}

government programs and/or entitlements for which she/her family may be eligible and how to get them

\section{Know that child} marriage is associated with poor health, poverty, and divorce (and that divorce carries social and economic risks) 


\section{Be able to assertively}

and respectfully navigate safe and healthy choices with regard to marriage

\begin{tabular}{l|l} 
Building & DEVELOPING \\
POSTIIE \\
Assets & BENCHMARKS \\
TOR ADOLESCENT \\
Toolkit & GIRLS
\end{tabular}

Know the location of a community center, the activities offered there, and how to participate 


\section{Know the location}

and hours of girl-only spaces 


\section{Know her own body parts and the body parts of the opposite sex}

\begin{tabular}{l|l} 
Building & DEVELOPING \\
POSSTIIE \\
Pssets & BENCHMARKS \\
Toolkit & FIRADLLESCENT \\
\hline
\end{tabular}

\section{Know the time of}

day/week when she is likely to face more risks at home, at school, on the street 


\section{Know when and where it is safe enough to go out alone (or when groups are safer)}

\section{Know her right}

to determine and communicate the number of children she wants and the timing of births 


\section{Know about sex}

trafficking and other forms of forced sex

(e.g., persuasion,

blackmail), and where

$$
\text { to get help }
$$

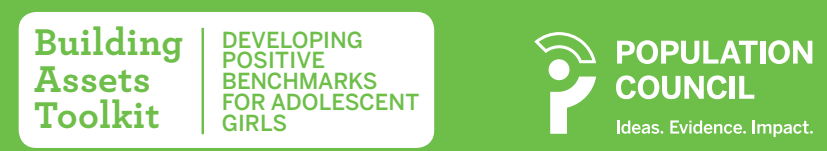

\section{Know the helpline number to register any violence or to get help}




\section{Know not to accept any food or drinks from strangers}

\section{Know that polygamy is illegal}




\title{
Know that she has the same rights as her brother
}

\begin{tabular}{l|l|}
\hline Building & DEVELOPING \\
Assets & PESTIVE \\
BENCHMARKS \\
Toolkit & FORADDLESCENT \\
GIRLS
\end{tabular}

\author{
2. POPULATION \\ COUNCIL \\ Ideas. Evidence. Impact.
}

\section{Have a plan to}

keep up her skills

(reading and

numeracy) during

school holidays 


\section{Know how to}

identify a safe water source

(or if in doubt to get

help testing it)

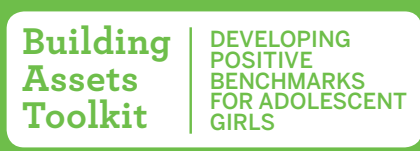

९阝 poovulation

Know how malaria

is contracted and

how to install and

maintain a bed net 


\section{Feel that she is as intelligent as other people}

Building DEVELOPING Assets BENCHMARK

Toolkit FGOADOLESCENT

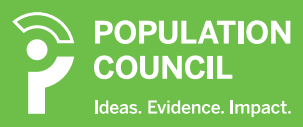

\section{Have a ration card}




\section{Know safe times/ routes to water}

sources and places to gather firewood, including during emergencies

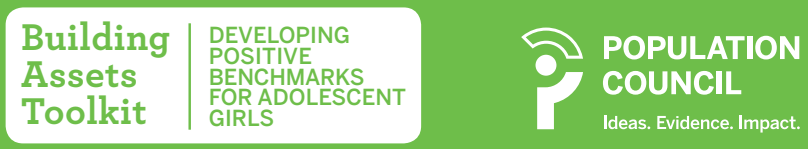

\section{Know someone}

who can help with

translation (to major

official languages),

as needed 


\section{Have a safety plan} and be able to name three safety risks faced while going about daily life

\section{Know the names of} trained people in the community who can

$$
\begin{aligned}
& \text { be relied upon } \\
& \text { to protect girls } \\
& \text { (the guardians) }
\end{aligned}
$$




\section{Stand up for herself and her friends when insulted}

\begin{tabular}{l|l}
\hline Building & DEVELOPING \\
POSTIIE \\
Assets & BENCHMARKS \\
Toolkit & FRRADOLESCENT \\
GIRLS
\end{tabular}

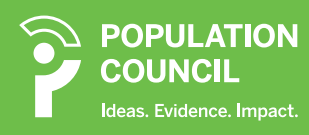

\section{Know how STIs,}

including HIV, can be prevented and their consequences (including infertility) 


\section{Know where to obtain condoms and contraceptives and where to obtain advice and instructions}

\begin{tabular}{l|l} 
Building & DEVELOPING \\
POSSTIIE \\
Pssets & BENCHMARKS \\
Toolkit & FIRADLLESCENT \\
\hline
\end{tabular}

\section{Know local health}

promoters and community-based health activities 


\section{Be able to present an argument to a group of peers and elders}

\begin{tabular}{l|l}
\hline Building & DEVELOPING \\
POSTIIE \\
Assets & BENCHMARKS \\
Toolkit & FORADOLESCENT \\
GIRLS
\end{tabular}

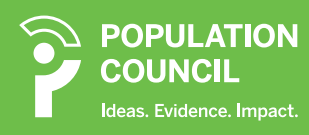

85

\section{Obtain parental approval to work and access safe} opportunities 


\section{Regularly practice}

reading and numeracy skills with the media available and in dailylife situations

\begin{tabular}{l|l|}
\hline Building & DEVELOPING \\
Assets & PESTIVE \\
BENCHMARKS \\
Toolkit & FORADDLESCENT \\
GIRLS
\end{tabular}

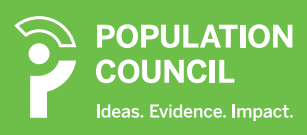

\section{Know how to read diagrams or maps}




\section{Know how to write a simple letter requesting something}

\section{Know how to write and send text}

messages and use mobile media to secure safety and access to resources 


\section{Know how to fill out forms}

\section{Know basic math}

(fractions, decimals,

and percentages)

and how to calculate

simple costs 


\section{Listen to the radio}

and watch television to get information

\section{Be able to express} feelings and notify a friend or trusted adult of a problem at school or at home 


\section{Use effective}

communication

and listening skills

(listen with empathy

and patience; speak

assertively not

aggressively)

\begin{tabular}{l|l} 
Building & DEVELOPING \\
Assets & PENIIIE \\
ToNCHMARKS \\
Toolkit & FORADLLESCENT \\
GIRLS
\end{tabular}

POPULATION
COUNCIL
Ideas. Evidence. Impact.

95

\section{Have the ability to}

de-escalate a conflict

situation experienced

among friends and

classmates 


\section{Manage anger when in stressful situations}

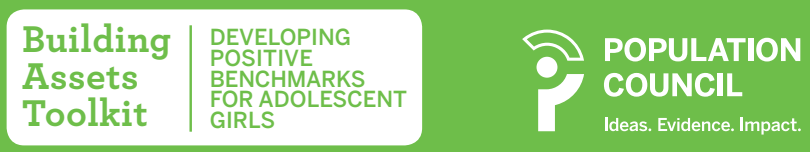

\section{Feel like she can say}

"no" to her friends if

they are pressuring

her to do something

she doesn't think is

$$
\text { right }
$$




\section{Know the symptoms}

of infectious diseases,

how to isolate an

individual, and where

to seek help

\begin{tabular}{l|l} 
Building & DEVELOPING \\
POSIIIE \\
Assets & BENCHMARKS \\
Toolkit & FORADOLESCENT \\
GIRLS
\end{tabular}

POPULATION
COUNCIL
Ideas. Evidence. Impact.

99

\section{Know that many diseases} are sexually transmissible (from both symptomatic and asymptomatic individuals) and some remain so even after

\section{recovery}




\begin{tabular}{l|l|}
\hline Building & PEVELOPING \\
Assets & POSITIVE \\
BENCHMARKS \\
Toolkit & FORADOLESCENT \\
GIRLS
\end{tabular}
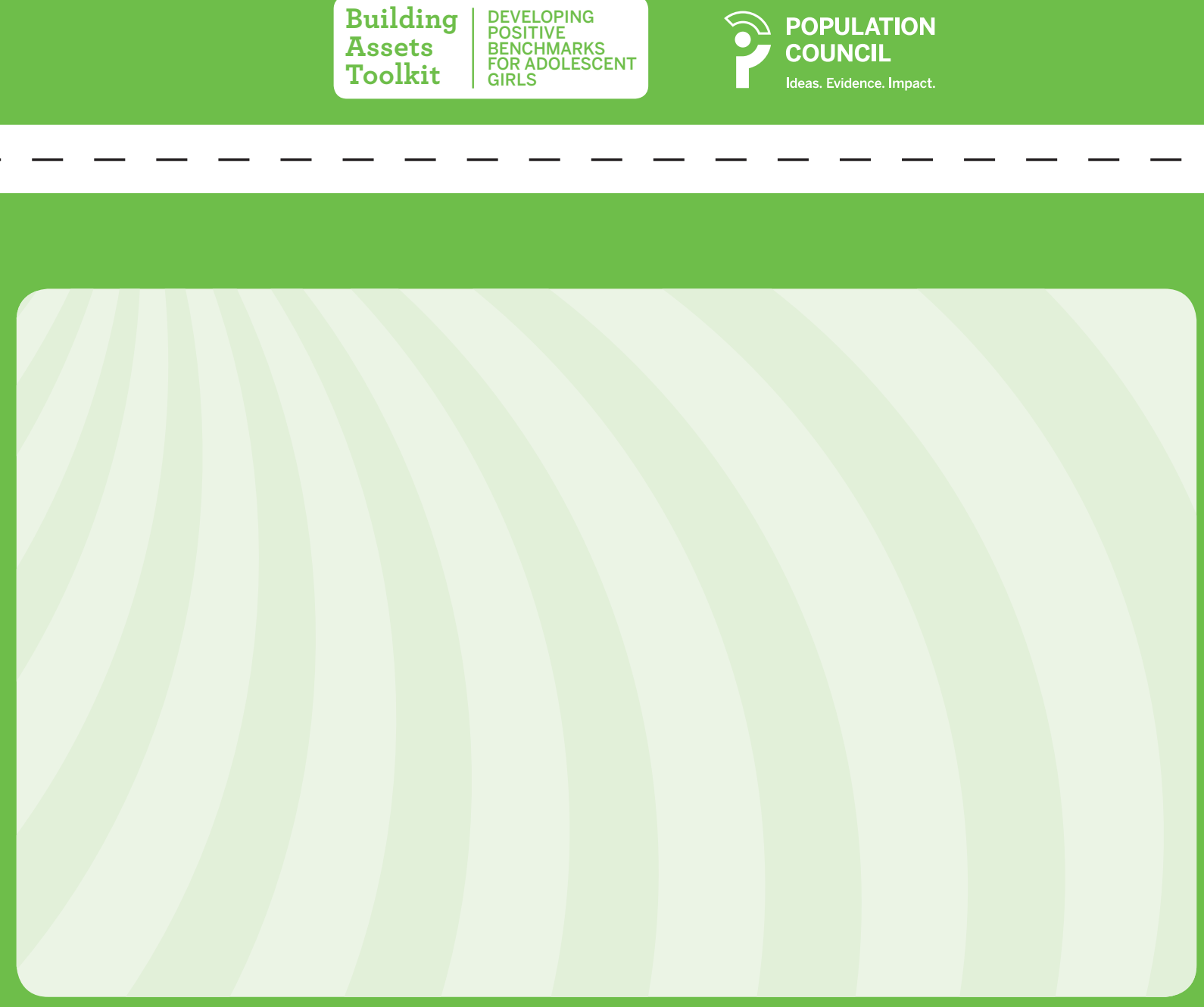


\begin{tabular}{l|l} 
Building & DEVELOPING \\
POSTIIE \\
Assets & BENCHMARKS \\
TOR ADOLESCENT \\
Toolkit & GIRLS
\end{tabular}
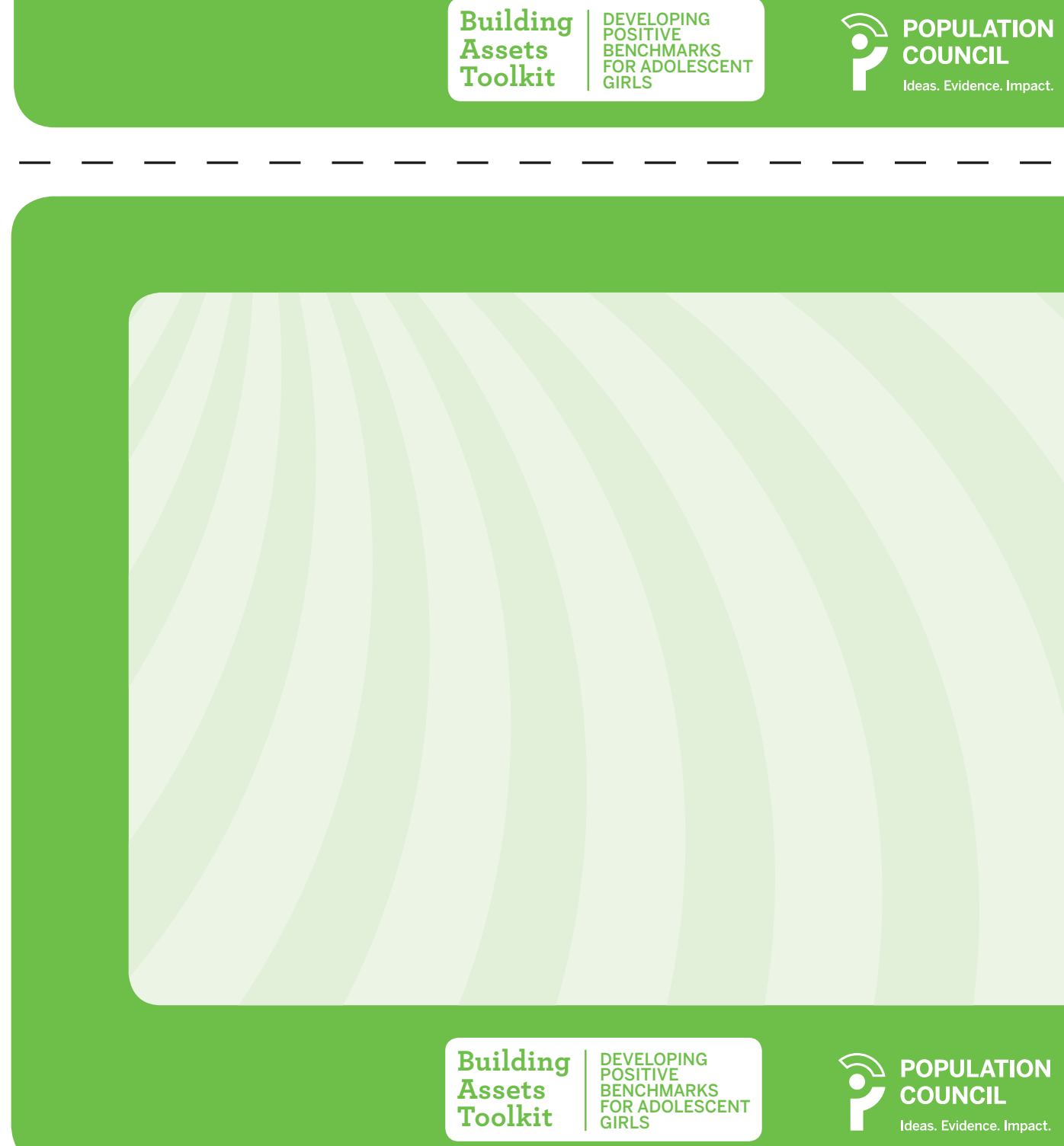


\begin{tabular}{l|l|}
\hline Building & PEVELOPING \\
Assets & POSITIVE \\
BENCHMARKS \\
Toolkit & FORADOLESCENT \\
GIRLS
\end{tabular}
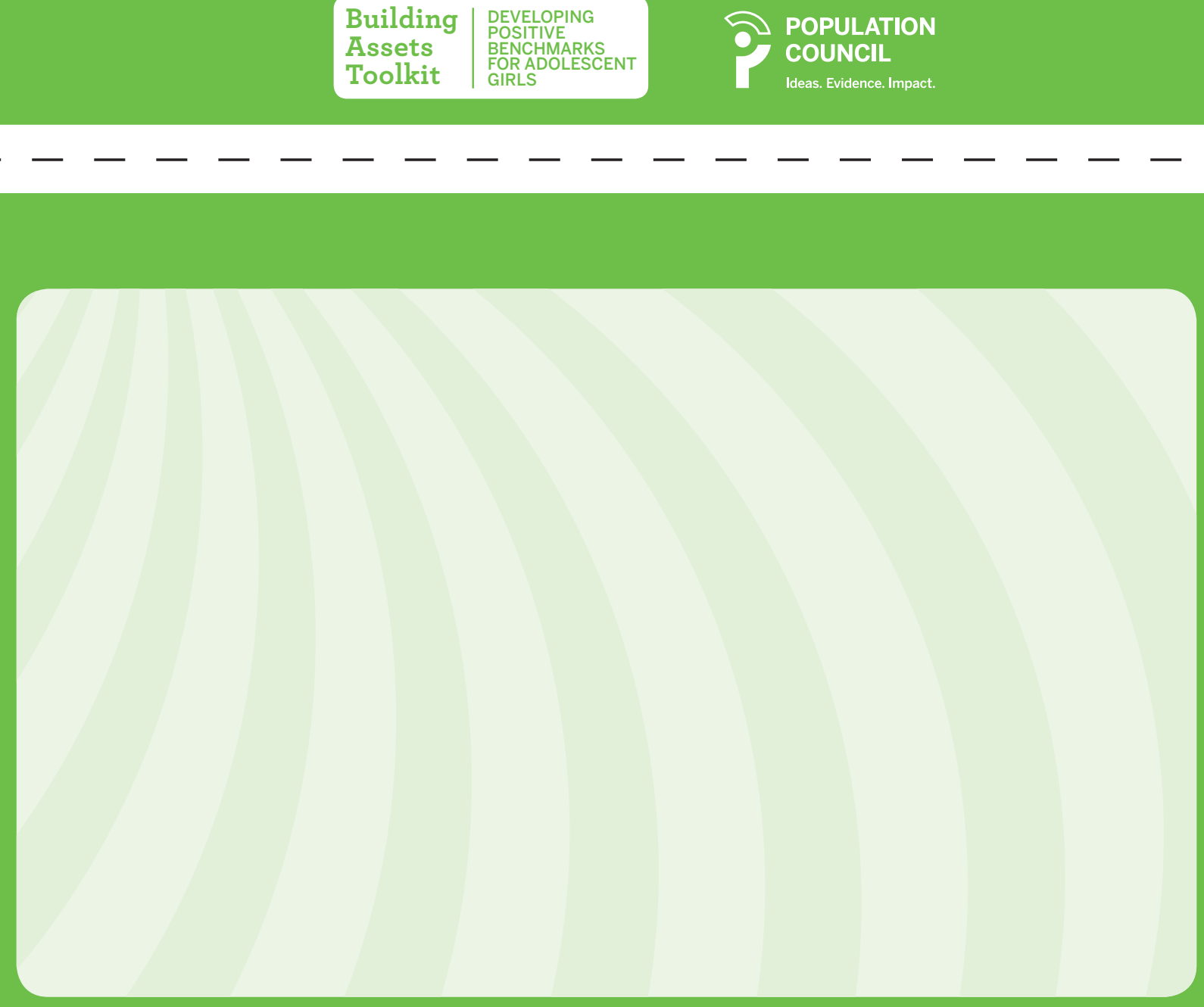


\begin{tabular}{l|l} 
Building & DEVELOPING \\
POSTIIE \\
Assets & BENCHMARKS \\
TOR ADOLESCENT \\
Toolkit & GIRLS
\end{tabular}
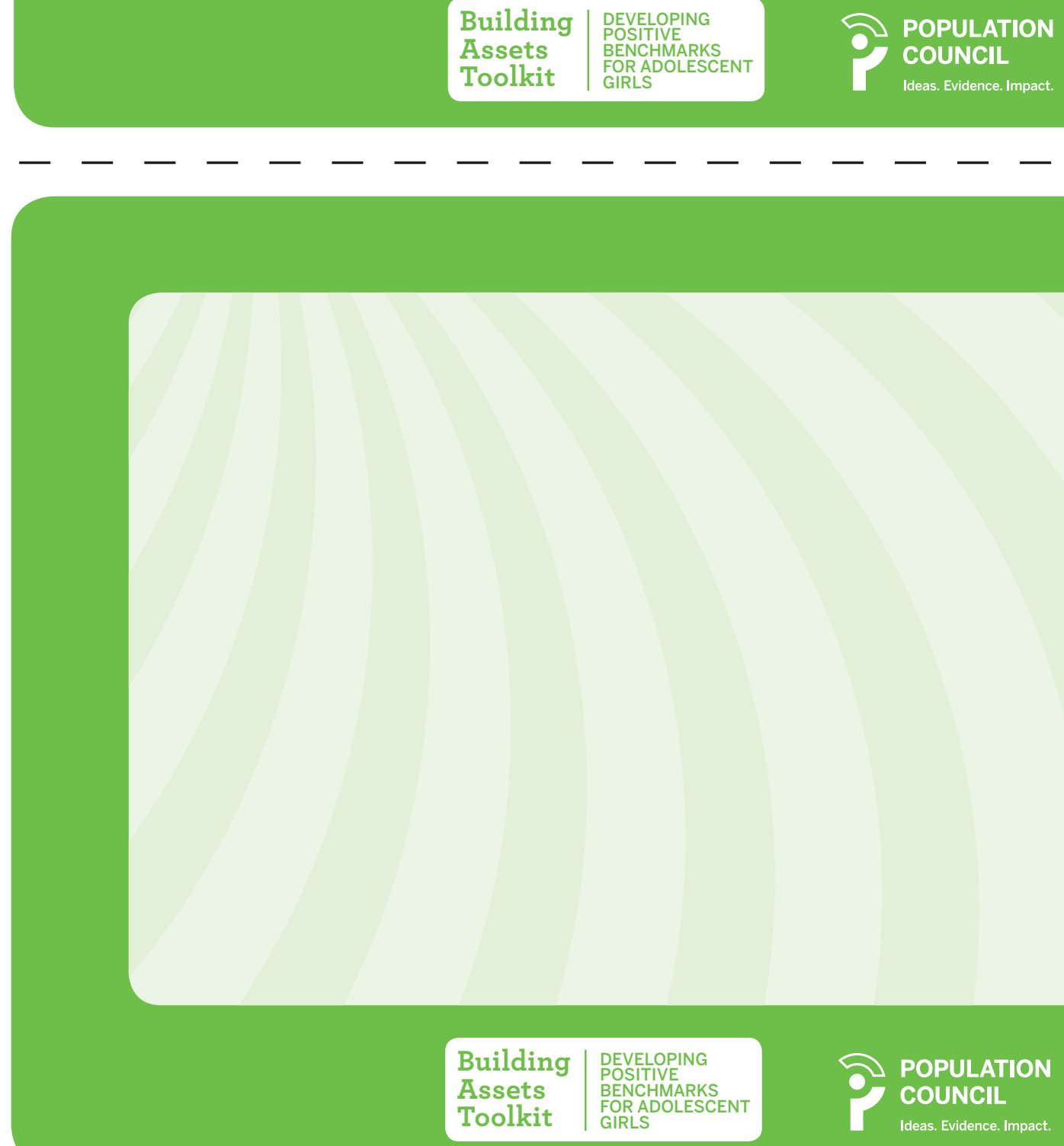


\begin{tabular}{l|l|}
\hline Building & PEVELOPING \\
Assets & POSITIVE \\
BENCHMARKS \\
Toolkit & FORADOLESCENT \\
GIRLS
\end{tabular}
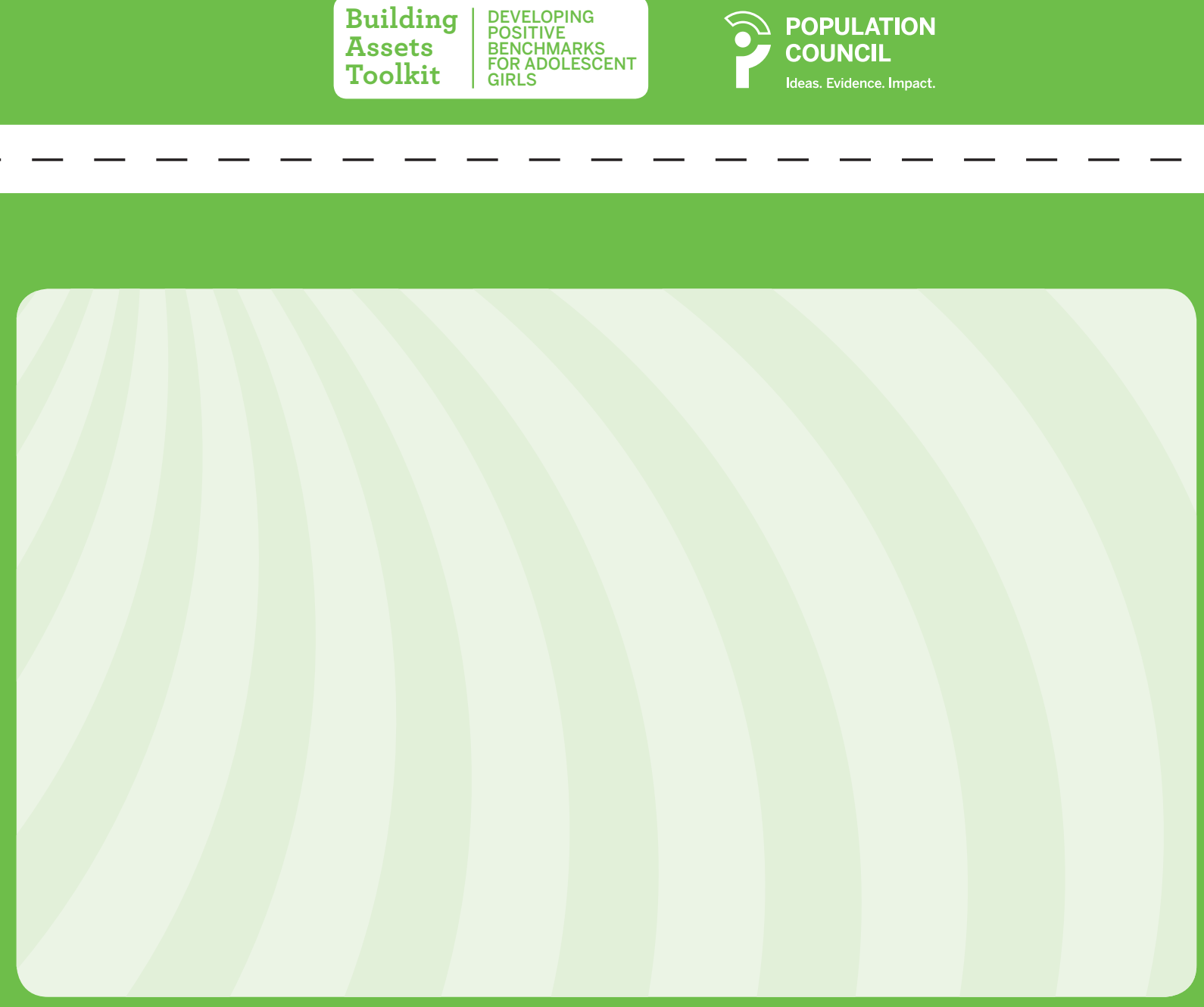
WORHSHEET CONTINUED ON NEXT PAGE

TAPE NEXT PAGE HERE

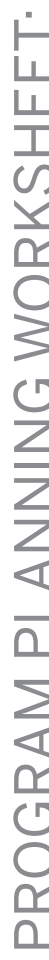




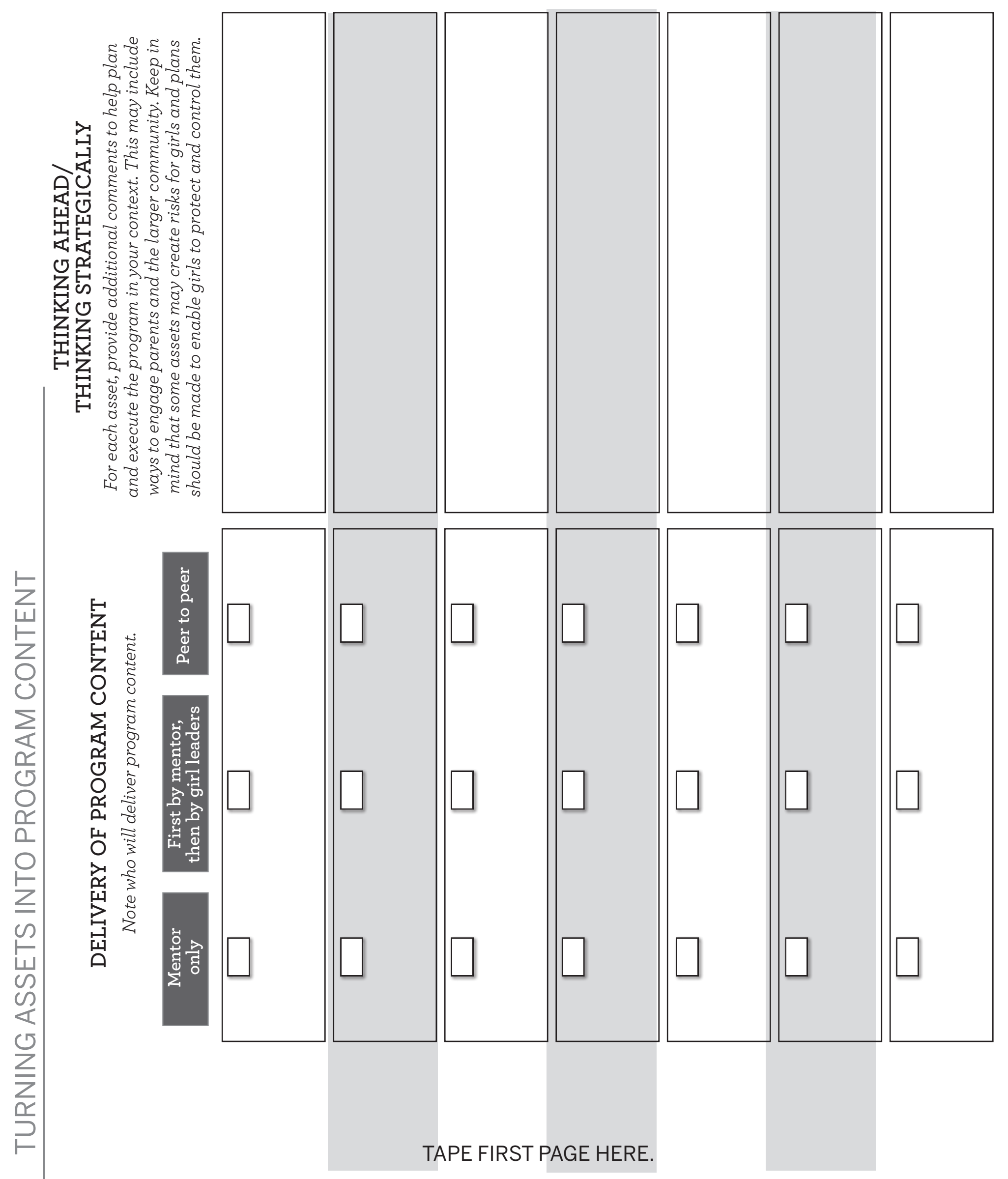




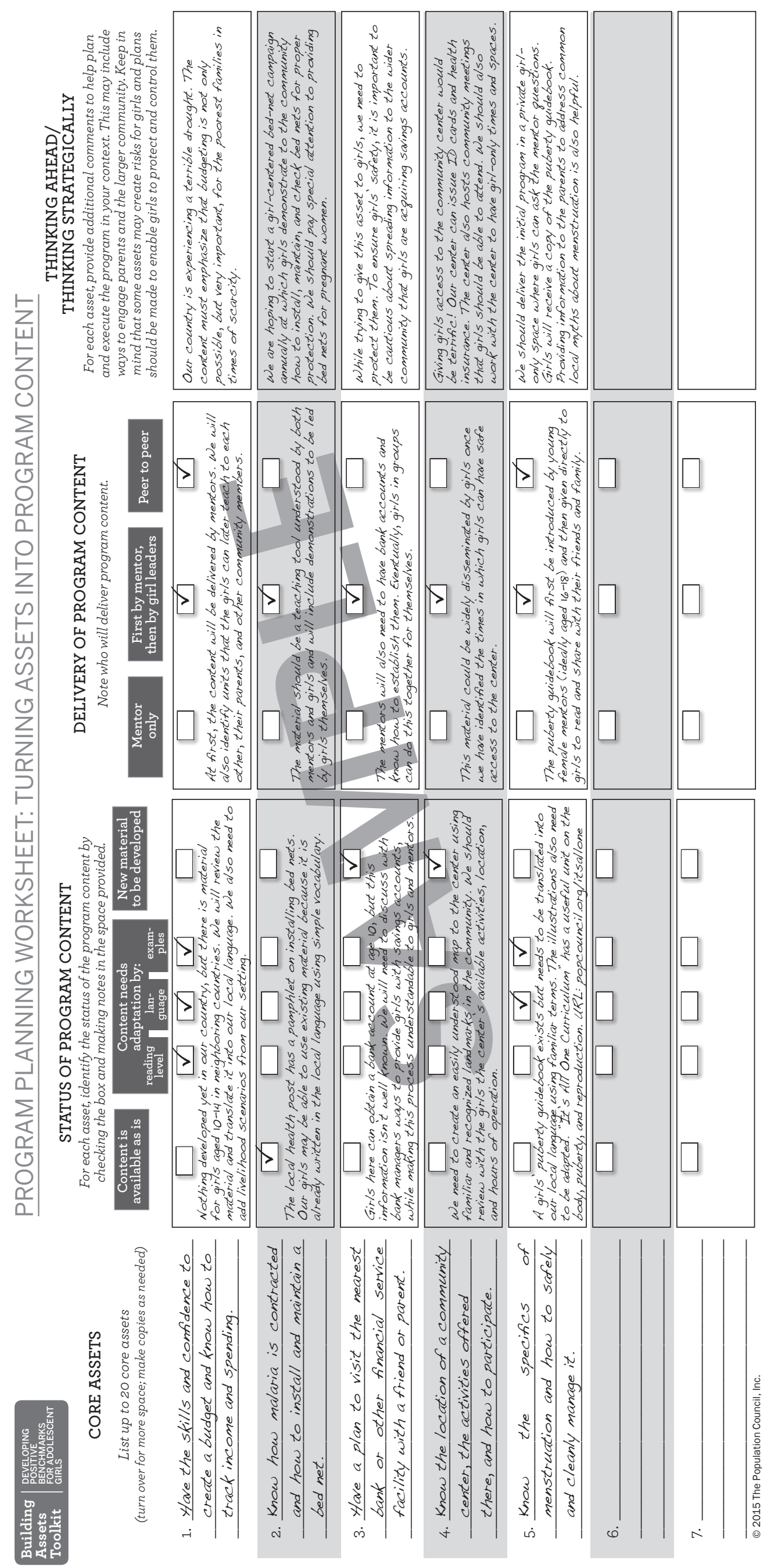

